CUADERNOS DE ESTUDIOS GALLEGOS, LX Núm. 126 (enero-diciembre 2013), págs. 225-253

ISSN: $0210-847 \mathrm{X}$

DOI: 10.3989/ceg.2013.126.06

\title{
EL MIEDO EN EL ESCENARIO DEL VIAJE ATLÁNTICO IBÉRICO, SIGLOS XV-XVI*
}

\author{
Vera Moya Sordo \\ Universidad Nacional Autónoma de México
}

\footnotetext{
El presente artículo deriva de una investigación más amplia: Vera Moya Sordo, Manifestaciones de miedo durante la navegación atlántica ibérica. Mediados del siglo XV a principios del siglo XVII, tesis de maestría inédita, México, Universidad Nacional Autónoma de México, 2011.
} 


\section{EL MIEDO EN EL ESCENARIO DEL VIAJE ATLÁNTICO IBÉRICO, SIGLOS XV-XVI}

\section{RESUMEN}

Durante los primeros viajes atlánticos que realizaron los ibéricos, primero por costas africanas y después hacia el horizonte occidental se manifestaron diversos miedos resultado, por un lado, de la sensación de peligro que despertaba la propia extensión marina, los seres que la habitaban y los fenómenos climáticos que allí se sucedían, y por el otro, del conocimiento de antiguos filósofos, mitos y creencias cristianas que relacionaban al mar con el infierno, el pecado y la muerte. En este sentido, los miedos no eran solamente respuestas a determinadas estimulaciones externas o internas, y fueron también causa y consecuencia de construcciones culturales e ideológicas frente el mundo natural. A través del análisis del discurso de diarios de viaje, crónicas y narraciones literarias de la época, se examinan diversos miedos que sorprendieron a aquellos navegantes: la lejanía de tierra; los padecimientos por sed, hambre y enfermedad; el encuentro con piratas o sirenas; así como los relacionados con la posibilidad de pérdida del barco: averías, malos pilotajes, tormentas, naufragios, además de señales del más allá que ponían a prueba la fe de los más devotos. Pese a los peligros, las naciones navegantes enfrentaron sus miedos impulsadas por el deseo de superar las adversidades y sobrevivieron a los viajes trasatlánticos ayudadas por la tecnología, pero sobre todo por la esperanza.

PALABRAS CLAVE: miedo, navegación, atlántico, ibéricos.

\section{O MEDO NO ESCENARIO DA VIAXE ATLÁNTICA IBÉRICA, SÉCULOS XV-XVI}

Resumo

Durante as primeiras viaxes atlánticas que realizaron os ibéricos, primeiro por costas africanas e despois cara ao horizonte occidental manifestáronse diversos medos resultado, por un lado, da sensación de perigo que espertaba a propia extensión mariña, os seres que a habitaban e os fenómenos climáticos que alí se sucedían, e polo outro, do coñecemento de antigos filósofos, mitos e crenzas cristiás que relacionaban ao mar co inferno, o pecado e a morte. Neste sentido, os medos non eran soamente respostas a determinadas estimulacións externas ou internas, e foron tamén causa e consecuencia de construcións culturais e ideolóxicas fronte o mundo natural. A través da análise do discurso de diarios de viaxe, crónicas e narracións literarias da época, examínanse diversos medos que sorprenderon aqueles navegantes: a distancia de terra; os padecementos por sede, fame e enfermidade; o encontro con piratas ou sereas; así como os relacionados coa posibilidade de perda do barco: avarías, malas pilotaxes, tormentas, naufraxios, ademais de sinais do alén que poñían a proba a fe dos máis devotos. Malia os perigos, as nacións navegantes enfrontaron os seus medos impulsadas polo desexo de superar as adversidades e sobreviviron ás viaxes trasatlánticas axudadas pola tecnoloxía, pero sobre todo pola esperanza.

Palabras Clave: Medo, Navegación, Atlántico, Ibéricos.

\section{FEAR OF THE IBERIAN ATLANTIC NAVIGATION, $15^{\mathrm{TH}}-16^{\mathrm{TH}}$ CENTURIES}

\section{Abstract}

During the first iberians atlantic travels, first along the african coast and then towards the western horizon, diverse fears manifested as a result of, on the one hand, the sense of danger that the own marine extension provokes, the beings inhabiting it and the weather events happening there, and on the other, of the knowledge of ancient philosophers, myths and christian beliefs that related the sea with the hell, sin, and death. In this sense, the fears were not only answers to certain external or internal stimulation, but they also were cause and consequence of cultural and ideological constructions toward the natural world. Through the discourse analysis of diaries, chronicles and literary narratives of the epoch, different fears that surprised those sailors are analyzed: the long distance to land; the thirst, hunger and disease suffering; the encounter with pirates or mermaids; as well as those related to the possibility of the ship loss: breakdowns, bad navigations, storms, shipwrecks, but also ominous signs from the other side that put to test the faith of the most devotee. However, despite the dangers, the sailing nations faced the fears motivated by the desire to overcome the adversities and survived the transatlantic travel helped by technology, but above all, hope.

KEY WORDS: fear, navigation, atlantic, iberian. 
Recibido/Received: 11/03/2013

Aceptado/Accepted: 06/09/2013

A principios del siglo XV, los viajes en caravanas hacia Asia y África permitieron a comerciantes, solados y exploradores, ser testigos de las "maravillas" de exóticos países desde Turquía y Medio Oriente, hasta la India, China y Cipango (Japón). Sin embargo, todavía había mucho territorio por explorar, sobre todo en la terrible extensión del Mar Océano (el Atlántico). Empujados por los vientos de la expansión comercial, portugueses y españoles se atrevieron a salir del mundo Mediterráneo y costero ibérico para inaugurar esos caminos ultramarinos poco explorados. Así, pusieron proa hacia el sur y recorrieron los contornos del continente africano hasta llegar al Mar Índico. Después se aventuraron hacia el horizonte occidental del Atlántico hasta topar con el "nuevo mundo". Joseph de Acosta escribió en su Historia Natural y Moral de las Indias (1590) que anteriormente a estos "descubrimientos", atravesar el infinito piélago de océano había parecido increíble y un completo desatino. Incluso los padres de la iglesia San Agustín y San Gregorio de Nacianceno, espantados de su inmensidad, creían que era imposible navegarlo después del estrecho de Gibraltar $^{1}$. Las raíces de este pensamiento se hallaban en la filosofía antigua y en el Génesis: al ser el aqua la materia esencial de la creación divina, el "gran océano" era "el padre de todas las cosas" do por ser un espacio abierto donde más allá de cierto límite, era imposible regresar $^{3}$. Pero las limitantes no eran solamente de orden psicológico y la auténtica peligrosidad del mar y el estado del arte de navegar de aquel entonces no habían permitido cruzar esa barrera. Ante la necesidad de recorrer mayores distancias con fines comerciales y de exploración, mediante viajes costeros y de isla en isla, ocurrió de manera paulatina una transformación de la visión predominantemente

\footnotetext{
1 Joseph de Acosta, "Libro primero, Capítulo XVI. De qué modo pudieron venir á las Indias los primeros hombres, y que no navegaron de propósito á estas partes", en Historia Natural y Moral de las Indias, Tomo Primero, Madrid, Pantaleón Aznar, 1792, pág. 47.

2 Guillaume de Conches (Philosophia Mundi) y Thierry de Chartres (Tractatus de sex dierum operibus), en Danielle LeCoQ, "De las aguas primitivas al océano infranqueable", en Alain Corbin y Hélène Richard, El mar. Terror y fascinación, Barcelona, Paidós, 2005, pág. 19.

3 Luís Adão da Fonseca, "O imaginário dos navegantes portugueses dos séculos 15 e 16", Estudios Avançados, 6 (18), 1992, pág. 42.
} 
oscura del mar hacia una más positiva que incluía la posibilidad de explorarlo a ultramar. Así, el Mar Océano se fue haciendo más navegable y los navegantes más conocedores de su entorno y más curiosos por descubrirlo. No obstante, una vez vencida la barrera del non plus ultra, comenzaron otras limitaciones de orden natural, técnico y psicológico. Aunque el arte de navegar y la cartografía y astronomía estaban bien constituidas y existía una marinería capaz de navegar prácticamente en cualquier mar del planeta, el mar seguía siendo peligroso en la complejidad de su ecosistema y los buques eran frágiles “cáscaras de nuez" para los largos viajes ultramarinos.

En este contexto se enmarca la presente travesía simbólica, en la cual se explorará la naturaleza de algunos de los miedos de quienes navegaron el Atlántico, desde del siglo XV, auge de las exploraciones portuguesas al África y las primeras incursiones castellanas y portuguesas al oeste, cuando añejos conceptos sobre el mundo y sus criaturas se enfrentaron ante una nueva realidad; hasta recorrer el siglo XVI, tiempo en el que el encuentro físico y espiritual con aquellos territorios comenzó a fundirse con lo cotidiano. Se expondrán tanto miedos individuales, como colectivos, algunos provocados por peligros externos que amenazaban la estabilidad del viaje y la existencia misma, así como otros de índole más psicológica, difíciles de entender por separado de los primeros y de la realidad circundante. Como veremos, no se trataba solamente del miedo al mar, sino a viajar en él, a la lejanía de tierra, a la soledad, a las tempestades, al asecho de piratas y otros seres, al pecado, al castigo y a la muerte.

Pero ¿qué es el miedo? Es una emoción tan vieja como la historia misma. Surge ante la noción de riesgo, pérdida de seguridad o de control sobre la realidad o su comprensión. Como respuesta innata de todo ser viviente a las amenazas, sean ciertas o imprecisas, desarrolla rasgos complejos en el hombre a través del recuerdo, provocando un estado de alerta (pasivo o activo) permanente que lo prepara para su defensa ${ }^{4}$. Pese a la dificultad de definirlo por pertenecer a la psique, su existencia es real y rastreable, ya que desde la Antigüedad ha sido objeto de complejas reflexiones filosóficas: Platón se refirió a déos (temor) en contraste al valor en su diálogo Laques (siglo IV a. C), mientras que Aristóteles disertó sobre phóbos (miedo) como una aflicción de la imaginación (phantasía) en su obra De anima, Retórica, Ética Nicomáquea y Ética Eufemia (siglo IV a. C). Después, Ammonio de Atenas (siglo II d. C) distinguió entre phóbos y déos: el primero un golpe presente producido por algo aterrador y el segundo la sos-

\footnotetext{
${ }^{4}$ Isabel Jáidar Matamoros, "De espanto y otros sustos", en Isabel Jáidar Matamoros (comp.), Los dominios del miedo, Área Subjetividad y Procesos sociales, México, UAM-XOCHIMILCO, 2002, pág. 104.
} 
pecha de un mal por venir ${ }^{5}$. En el contexto europeo occidental medieval, Santo Tomás de Aquino, en la Suma Theologiae (siglo XIII), síntesis del pensamiento filosófico greco-latino, propuso que tanto metus como timor eran provocados por un mal próximo producto de la ilusión ${ }^{6}$. Siglos después, en el diccionario monolingüe Tesoro de la Lengua Castellana Española (1611) de Sebastián de Covarrubias, el miedo, temor y horror son sinónimos y aparecen tanto al instante presente como en el futuro, en los temerosos y los temerarios ${ }^{7}$. Como se puede apreciar, la esencia de su significado se mantuvo uniforme en el pensamiento clásico y en sus herederos medievales y modernos, como una emoción provocada por un mal o peligro, real o imaginario, inmediato o por venir. Esta misma propiedad se mantiene hasta hoy en día, por lo que su significado para los hombres de los siglos XV o XVI no dista mucho del sentido actual de la emoción. Sin embargo, como expresó Jean Delumeau, los temores cambian según el tiempo y los lugares en relación con las amenazas que abruman ${ }^{8}$.

A pesar de su añeja presencia, en el campo de los estudios sociales el miedo ha sido relegado a las brumas de su propia historia. En opinión de Delumeau, ello se debe a la incomodidad que despiertan los temas de la irracionalidad y la subjetividad, pues su estudio es una tarea mucho más compleja que el análisis de hechos históricos concretos ${ }^{9}$. Desde hace tiempo, disciplinas como la biología, la sociología y el psicoanálisis se han interesado en su estudio, y hace algunas décadas, la historia comenzó a considerarlo, junto con otras emociones, tema de investigación en el campo de las ideas, la cultura y las mentalidades. Una de las obras más importantes de la historiografía sobre el tema es El miedo en Occidente del mismo Delumeau, donde se aborda por extenso al miedo y la colectividad de las sociedades occidentales, dedicando un capítulo específico al mar, espacio donde el historiador está seguro de encontrarlo sin ninguna máscara ${ }^{10}$. Pese a sus "fronteras" intangibles y fugaces, ha sido posible comprender su papel en el acontecer humano a la luz de la razón histórica, al encontrarlo en la cons-

\footnotetext{
5 Vicente Domínguez, "El miedo en Aristóteles", Psicothema, vol. 15, núm. 4 (2003), págs. 662665 [en línea], disponible en <http://psicothema.com> [Consulta: 03/08/ 2009]

6 Dolores Pralon-Julia, "Una teoría del miedo en el siglo XVII: el De metu... de Cabreros de Avendaño", Criticón, núm. 23, 1983, pág. 6 [en línea], disponible en <http://cvc.cervantes.es> [Consulta: 19/08/2009] .

7 Sebastián de Covarrubias, Tesoro de la Lengua Castellana o Española (1611), Barcelona, Horta, 1943, pág. 794.

8 Jean Delumeau, "Miedos de ayer y de hoy", en Marta Inés Villa Martínez (ed.), El miedo. Reflexiones sobre su dimensión social y cultural, Medellín, Corporación Región, 2002, pág. 11.

9 Joanna Bourke, "Fear and anxiety: writing about emotion in Modern History", History Workshop Journal, 55, 2003, pág. 111.

${ }^{10}$ Jean Delumeau, El miedo en Occidente (siglos XIV-XVIII). Una ciudad asediada, Madrid, Taurus, 1989, pág. 53.
} 
trucción singular y colectiva de la realidad ${ }^{11}$. Así lo demuestran estudios como el de Stuart Walton, Humanidad. Una historia de las emociones (2004), donde el miedo es uno de los agentes elementales en la formación de la historia; y de Joanna Bourke, El miedo: una historia cultural (2005), en la que se examinan temores como a la muerte, a Dios, a la enfermedad y al crimen en Gran Bretaña, Norteamérica y Australia entre finales del siglo XIX y finales del XX.

Por su parte, entre los estudios latinoamericanos se encuentran El miedo. Reflexiones sobre su dimensión social y cultural (2002), compilado por Marta Inés Villa Martínez, que lo aborda desde una dimensión social en el mundo occidental y latinoamericano; y El miedo en el Perú. Siglos XVI al XX (2005), de Claudia Rosas Lauro (comp.), un recorrido interdisciplinario por los miedos que se desarrollaron en el Perú en los últimos cinco siglos. Mientras que en México destacan tres publicaciones: Los dominios del miedo (2002) de Isabel Jáidar Matamoros (ed.), diversos estudios en torno al miedo a la muerte, la religión, la locura, los "espantos" y la inseguridad pública; así como Los miedos en la historia (2009), coordinado por Elisa Speckman Guerra, Claudia Agostoni y Pilar Gonzalbo Aizpuru, y Una historia de los usos del miedo (2009), coordinado por Pilar Gonzalbo, Anne Staples y Valentina Torres Septién. En el primero se analizan los orígenes de los miedos a través de fenómenos como la enfermedad, el deshonor, la pobreza, la muerte o el olvido, y su relación con las costumbres culturales y morales en México. En el segundo libro se reflexiona sobre aspectos del miedo colectivo en torno al cuerpo femenino, el tránsito a la muerte, el crimen, entre otros, y su utilización como argumento a favor de intereses particulares que en algunos casos justificó la violencia.

Con relación a los navegantes y el imperio del miedo, el mar, se ha mencionado en destacados estudios como los de John. H. Parry, El imperio marítimo español (1966) y El descubrimiento del mar (1973); en los de José Luis Martínez sobre Pasajeros de Indias. Viajes trasatlánticos en el siglo XVI (1999) y El mundo privado de los emigrantes de Indias (2007); los de Michel Mollat Du Jourdin, como La vida cotidiana de la gente de mar en el Atlántico de los siglos IX-XVI (1983) y Europa y el Mar (1993); de Pablo Emilio Pérez-Mallaína, Los Hombres del Océano, Vida cotidiana de los tripulantes de las flotas de Indias, Siglo XVI (1992) y El hombre frente al mar. Naufragios en la carrera de indias durante los siglos XVI y XVII (1996); de Luís-Adão da Fonseca, Do Imaginário do Atlântico ao Atlântico Imaginado (en colaboración con José Adriano F. de Carvalho, 1993), y "O imaginário dos navegantes portugueses dos séculos 15 e 16" (Estudios Avancados, 1992); y João Silva de Souza, 1394-1494: do Infante a Tordesilhas (1995), por mencionar algunos. Pero en ellos el miedo ha figurado

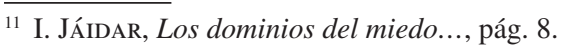


solo como acompañante silencioso durante las travesías oceánicas y no como objeto de estudio. Sin embargo, existen estudios más próximos al tema de las emociones que despierta el mar, como los de Alain Corbin, El territorio del vacío. Occidente y la invención de la playa. 1750-1840 (1993), donde se analiza el sentido que fue adquiriendo la costa para el descanso y la recreación; así como El mar. Terror y fascinación (2005), en coordinación con Hélène Richard, que integra lo positivo y negativo de dichas emociones, abordadas a partir de textos de la antigüedad clásica, la Biblia y el Génesis, así como reproducciones gráficas y pictóricas de diversas épocas. Existen pues, escasos estudios que traten al miedo como sujeto histórico y menos aun en su relación con la navegación durante las primeras travesías por el Atlántico.

A lo largo de la presente investigación, el miedo fue una sombra constante ante las circunstancias particulares del viaje en carabelas y naos por mares recién explorados; exacerbado por la memoria ancestral y reciente anidada en el inconsciente individual y colectivo; y exaltado en ocasiones por la posibilidad de la muerte. Así, se encuentra presente en diarios de viaje, crónicas de navegación y cartas privadas, que fueron analizados en sus originales o en publicaciones en historias generales, compendios o estudios críticos. Algunos de ellos son El libro de la primera navegación y descubrimiento de las Indias $(1552)^{12}$ y la Historia de las Indias (1566) $)^{13}$ en el cual Bartolomé de las Casas copió y resumió parte del diario de Colón sobre su primer y tercer viaje; y la Historia del almirante Don Cristóbal Colón de Hernando Colón ${ }^{14}$, en la trascripción que aparece en Historiadores primitivos de las Indias Occidentales de Andrés González Barcia (Madrid, 1859). Del Primer viaje alrededor del mundo de Fernão Magalhães y Juan Sebastián Elcano, escrito por Antonio Pigafetta y publicado por primera vez en París en 1525 y posteriormente en otras ediciones en distintos idiomas, se revisó Relación del primer viaje alrededor del mundo. Noticias del mundo nuevo con las figuras de los paises que se descubrieron señalados (España, Red ediciones, 2011), traducción de la edición crítica de Camilo Manfroni

\footnotetext{
${ }^{12}$ La copia de este manuscrito fue descubierta por Fernández de Navarrete en 1790 y publicada en 1825. Se titula originalmente: "Este es el primer viaje y las derrotas y camino que hizo el almirante don Cristóbal Colón quando descubrió las Yndias puesto sumariamente sin el prologo que hizo a los reyes que va a la letra y comienza de esta manera: In Nomine Domini Nostri Jesu Christi”, Biblioteca Nacional de España, Sección de Manuscritos, Vitrina 6, número 7-8; Biblioteca Digital Hispánica, [en línea], disponible en <http://bibliotecadigitalhispanica.bne.es/view/action/nmets. do> Consulta: marzo de 2013] .

${ }^{13}$ Los tres volúmenes del manuscrito Historia de las Indias se localizan en la Biblioteca Nacional de España, Sede de Recoletos, Sala Cervantes, Fondo Antiguo, MSS/2812.

${ }^{14}$ Historie del S. D. Fernando Colombo; nelle s'ha particolare et vere relatione della vita e de fatti dell'Almiraglio D. Christoforo Colombo suo padre (Venecia, 1571), cuyo original se encuentra en la Biblioteca Nacional de España, Sede de Recoletos, Sala Cervantes, Fondo Antiguo, R/31285.
} 
$(1928)^{15}$. Asimismo, se examinaron las relaciones de naufragios descritas por Gonzalo Fernández de Oviedo en su Historia General y Natural de las Indias, especialmente el libro (L) dedicado a los infortunios y naufragios (1535); además de aquellas de los portugueses por las costas africanas durante los siglos XVI y XVII, compiladas a manera de lecturas ejemplares por Bernardo Gomes de Brito en la Historia Trágico-Marítima (publicada por primera vez en dos volúmenes entre 1735 y 1736) ${ }^{16}$. Asimismo, se consultaron las crónicas de Fray Antonio de Guevara, (1539), Fray Tomás de la Torre (1554,) y Eugenio de Salazar (1573), reunidas a manera de apéndices en Pasajeros de Indias. Viajes trasatlánticos en el siglo XVI de José Luis Martínez (1999); así como la magnífica compilación de Enrique Otte de Cartas privadas de emigrantes a Indias, 1540-1616 (1996).

También fue útil la literatura marítima de la época, otro tipo de representación de la vida cotidiana de los hombres de mar y de sus andanzas y pesares en el vaivén de los viajes ultramarinos, que permitieron un acercamiento particular al mundo de los navegantes. Algunas de las obras consultadas para este texto (en ediciones actuales) son La Dragontea (Madrid, 1598), epopeya de Lope de Vega sobre el enfrentamiento naval entre las fuerzas españolas y el corsario Francis Drake en aguas del Atlántico y el Caribe en 1596, basándose en diversos testimonios de la Real Audiencia de Panamá17, así como la novela de Miguel de Cervantes El amante liberal (1613), impregnada de las tribulaciones de la vida marítima que el autor conocía por propia experiencia y que en momentos son descritas de una manera realista.

Para aproximarse al miedo en estas fuentes de origen y características diversas, se partió de la idea de Bourke de que éste no solamente sigue los usos del lenguaje, sino posee su propia narrativa, al comunicarse a través de determinadas estructuras de género, sintaxis, forma, orden y vocabulario; de manera que si en un texto se emplea una palabra relacionada como "asustado", "temeroso" o "aterrorizado", no hay duda que se refiere al miedo en sí1 ${ }^{18}$. Pero además, se

\footnotetext{
${ }^{15}$ Basada en otro original de Pigafetta: La mia longa et pericolosa navigatione (la prima circumnavigazione del globo 1519-1522), conservado en la Biblioteca Ambrosiana de Milán.

${ }^{16}$ História trágico-marítima, em que se escrevem chronologicamente os naufragios que ti veram as naus de Portugal, depois que se poz em exercício a Navegação da Índia, Lisboa, na Off. da Congregação do Oratório; Tomo I, 1735, y Tomo II, 1736. Conformado por historias que fueron escritas originalmente por los propios sobrevivientes o testigos de los sucesos, muchos de ellos anónimos, y arregladas más tarde por Gomes de Brito para su compilación.

${ }^{17}$ La Dragontea fue publicada por primera vez en 1598 en la imprenta valenciana de Pedro Patricio Mey, sin el permiso del Consejo de Castilla. Tras varios intentos fallidos de ganar la licencia para publicarla, pues se le consideraba una obra que faltaba a la verdad de los hechos, otorgando la gloria de la victoria a quien no la merecía (lo que reflejó ciertas discrepancias políticas entre las mismas autoridades que dirigieron la campaña), finalmente fue publicada de manera disimulada junto con La hermosura de Angélica y las Rimas en una edición de Madrid de 1602.

${ }^{18}$ J. Bourke, "Fear and anxiety...", pág. 121.
} 
encuentra detrás de ciertas expresiones del lenguaje que indican que alguien se halla "paralizado" o "histérico" o cuando se describen acciones de defensa o resguardo ante algo considerado peligroso. Asimismo, para comprender estos miedos en su contexto, se analizaron tanto los elementos escritos internos que caracterizaron las fuentes, como los externos que pudieron influirlas y determinarlas; eso es, los lugares y procesos sociales y políticos de la época, así como los propios intereses y vivencias del autor. Aunque en principio se entiende que un diario de viaje narra un hecho "real" y una novela tiene una gran carga de ficción, en este caso son fuentes históricas pertenecientes a una misma época que trasmiten visiones distintas de una realidad, por lo que fueron interpretadas de acuerdo a su propósito y contexto. Por lo mismo, se evaluaron los parámetros del discurso, tratando de distinguir entre los elementos "ficticios" y los hechos históricos, considerando además las circunstancias que rodearon a la obra, sin la pretensión de juzgar lo que era "verdad" o "mentira", sino de comprender mejor la interacción de ambos en los sucesos referidos. Por ejemplo, se comprende que el diario de Cristóbal Colón o la crónica de Antonio Pigafetta, obedecieron a necesidades y expectativas distintas que la de Fernández de Oviedo o Gómez de Brito. Los dos primeros pretendían ser testimonios puntuales de lo sucedido durante las expediciones y no fueron elaborados deliberadamente para su divulgación general, pues contenían información valiosa y secreta para las naciones promotoras de los viajes. En cambio, la Historia General y Natural de las Indias de Fernández de Oviedo fue un encargo oficial por parte de Carlos V con el propósito de hacer públicos los hechos memorables de la empresa española, de manera que su finalidad fue visiblemente propagandística y monárquica ${ }^{19}$. Por su parte, la Historia Trágico-Marítima es un compendio de historias basadas en sucesos reales que en su momento fueron publicadas por separado en panfletos o cuadernos literarios y cuya estructura narrativa se centra en el horror de los naufragios y los sufrimientos de sus víctimas a manera de relatos aleccionadores, expresando ideologías y creencias de la cultura portuguesa en su carrera por el comercio oriental.

Como se verá en los testimonios que se presentan a continuación, estos se encuentran impregnados de lo "maravilloso" y aleccionador, viniesen de un capitán de navío, de un oficial de la administración, de un pasajero o de un marinero común, incluso de la pluma de un narrador o compilador posterior. No obstante, su legitimidad y significado histórico es comprensible en las circunstancias espaciales y sociales que les rodearon. En aquel entonces, las travesías largas y peligrosas eran consideradas acontecimientos extraordinarios, por ello,

\footnotetext{
${ }^{19}$ Luis Gil Fernández, Los Studia Humanitatis en España durante el reinado de los Reyes Católi$\cos$, Universidad Complutense de Madrid, [en línea], disponible en <http://ler.letras.up.pt/uploads/ ficheiros/2957.pdf> [Consulta: 11/05/2008].
} 
sus narraciones se realizan con una gran carga emocional y mística, creando un entorno que pudiera parecer ficticio o irreal, pero que encierra hechos verídicos identificables ${ }^{20}$ y comprensibles en el contexto de los primeros viajes trasatlánticos ultramarinos.

Por último, si bien los temores que aquí se exponen no son representativos de todos lo que pudieron sentir aquellos hombres, pues hay tantos miedos como motivos, personas y situaciones; son importantes para comprender el contexto cultural e ideológico de los marineros y pasajeros en sus primeras travesías atlánticas, así como los efectos, tanto negativos como positivos, de esta emoción dentro del conjunto de conexiones e interacciones sociales de la época.

\section{NAVEGAR EL MUNDO ATLÁNTICO}

A mediados del siglo XV, mientras que al norte del Atlántico los bretones pescaban en las costas de las llamadas "tierras nuevas" (Islandia) ${ }^{21}$ y los ingleses e italianos realizaban exploraciones en búsqueda de la mítica "Brasil", la costa noroccidental africana y sus islas Canarias, Madeira y Azores eran lugar de actividades mercantiles, principalmente de portugueses, quienes habían logrado avanzar en el contacto comercial y diplomático con los pueblos africanos y se alistaban para ir más lejos y encontrar el acceso al mar Índico; pero antes hubo que superar varios obstáculos. El primero fue el Cabo Bojador (1434), conocido como "Cabo de miedo", donde se pensaba que los mares ardían al caer siniestras cascadas de arenas rojas, y tiempo después, tras avanzar por la costa occidental africana y sortear otros puntos geográficos como Cabo Blanco (1441), Cabo Verde (1445), el Golfo de Guinea (1452), la línea del Ecuador (1471) y el estuario del río Congo (1482), arribaron al Cabo "de las Tormentas" en $1488^{22}$, donde la flota de Bartolomeu Dias casi naufraga en su intento por continuar su camino. Finalmente, tras este periplo de dificultades, la expedición de Vasco da Gama logró llegar a la India en 1498. Por su parte, cinco años antes de esta última hazaña, Cristóbal Colón se aventuró al oeste y tras atravesar el inquietante espesor del Mar de los Sargazos, avistó la isla de San Salvador, Bahamas. Otros viajes de exploración se realizaron desde entonces hacia el occidente. Además de los tres viajes de Colón que durante 1493-1504 lo llevaron a la búsqueda del estrecho que creía atravesaba las nuevas tierras hacia el mar Índico, tuvieron lugar

\footnotetext{
${ }^{20}$ Vera Moya SoRdo, "Miedo en el navío inestable. Navegaciones atlánticas hispánicas, siglos XVXVII", Traversea: Journal of Trasatlantic History, vol. 2 (2012), pág. 118 [en línea], disponible en $<$ http://www.uta.edu/history/traversea/ojs/index.php/traversea/article/view/28>.

${ }^{21}$ Jean Favier, Los grandes descubrimientos. De Alejandro a Magallanes, México, Fondo de Cultura Económica, 2004, pág. 82.

${ }^{22}$ Que una vez superado fue rebautizado por el rey de Portugal como Cabo de Buena Esperanza.
} 
el de Alonso de Ojeda, Juan de la Cosa y Amerigo Vespucci (1499-1502) para buscar igualmente el estrecho, descubriendo que el "nuevo mundo" se trataban de un continente; el de Pedro Álvares Cabral que al navegar por el sur-oeste en busca de islas que sirvieran de escala dio accidentalmente con Brasil; así como la odisea que llevó a Fernão de Magalhães a encontrar el estrecho y descubrir el Océano Pacífico en 1520.

Tras este encuentro de mundos, en poco tiempo el Reino de Castilla logró establecer los virreinatos de Nueva España y el Perú, además de monopolizar la navegación trasatlántica entre Europa y América. Por su parte, aunque la principal orientación de Portugal continuaba siendo la política y el comercio con los pueblos de África y Asia, no desaprovechó las posibilidades comerciales que ofrecía el nuevo mundo y estableció colonias en la mayor parte de la costa atlántica norte de América del Sur (Brasil). Para entonces la ruta marítima trasatlántica de ida y vuelta desde Europa a las colonias americanas era prácticamente la misma que había navegado Colón desde su primer viaje y se recorría en 25 a 30 días, a veces el doble, según las condiciones de navegación. Las temporadas en que se realizaban los viajes variaban dependiendo de las circunstancias climáticas, lo que resultaba bastante complicado, pues por ejemplo cuando en el hemisferio Norte era verano, en las costas peruanas al sur del ecuador era invierno ${ }^{23}$. Mientras que las zonas de mayor peligro se encontraban en el Golfo de México, Bahamas y Bermudas, sobre todo durante junio, julio y agosto, así como de octubre a abril, cuando los nortes, ciclones y huracanes azotaban con fuerza. Ello, como puede esperarse, aunado a la natural peligrosidad de las zonas de cayos y arrecifes, volvían muy riesgosa la navegación atlántica.

\section{MiedOS A BORDO}

\section{La infinita lejanía}

Como se ha dicho, el espacio Atlántico impresionaba, sobre todo en su enormidad dilatada hacia el oeste y su desnudez de tierras donde ampararse durante la mayor parte del viaje. Al comienzo de la exploración trasatlántica, las dimensiones del mundo seguían siendo cosa de especulación. Se sabía que los viajes podían ser muy extensos e inciertos, de manera que quienes los financiaban albergaban serias dudas sobre la viabilidad de aquellas empresas. Los detractores de los primeros viajes, los consejeros y sabios de las cortes portuguesa y española, argumentaban una y otra vez lo inaudito que resultaba la extensión a recorrer.

\footnotetext{
${ }^{23}$ José Luis Martínez, Pasajeros de Indias. Viajes trasatlánticos en el siglo XVI, México, Fondo de Cultura Económica, 1999, págs. 11-80.
} 
Es comprensible entonces que en sus primeras expediciones, capitanes como Colón y Magalhães ocultasen a su tripulación, incluso a algunos de sus oficiales, los cálculos "reales" de aquellas distancias. Dicha cautela era para evitar que los hombres temieran embarcarse hacia un destino incierto e impidieran el cometido de la empresa. En ambos casos el argumento fue el mismo. El cronista del primer viaje alrededor del mundo, Antonio Pigafetta, explicaba que lo mejor era que lo ignorara la gente para que a nadie aterrara el emprender tan grande y estupenda cosa, en un mar donde habitan vientos impetuosos y caprichosos azares ${ }^{24}$.

Sin embargo, con el pasar de los días y las noches sin señal de tierra, la determinación de ocultar una verdad tan evidente acababa por tambalearse ante la sospecha colectiva. Por ello, el primer viaje de Colón casi termina en un amotinamiento. Tras una prolongada navegación, la tripulación comenzó a alarmarse ante la fuerza de los vientos alisios que impulsaban los navíos hacia el oeste, lo que les hizo creer que no habría vientos contrarios que favorecieran su regreso a España. Aunque Colón se libró del apuro gracias a la súbita aparición de éstos, la serenidad de ánimos no duró mucho tiempo ya que al día siguiente se hallaron en una situación inversa, con algunas horas de ausencia de vientos, lo que motivó nuevamente la inquietud de los hombres, quienes decían que por allí no avía mar grande, que nunca ventaría para bolver a España $[\ldots]^{25}$.

En la biografía que escribió sobre su padre, con motivo de resaltar su vida y cualidades, tanto personales como navales, Fernando Colón refirió que conforme pasaba el tiempo y la tripulación buscaba señales de tierra en vano, más aumentaba su angustia y murmuraban que el Almirante

con su loca fantasía, havia resuelto hacerse Gran Señor, a costa de sus vidas, i peligros, i morir en aquella Empresa, i que puesto que ia havian satisfecho a su obligación de tentar la fortuna, i estaban tan remotos de Tierra, $i$ de todo socorro mas que de otros algunos, no debían, siguiendo el viaje, ser autores de su propia ruina... ${ }^{26}$

\footnotetext{
${ }^{24}$ Antonio Pigafetta, Relación del primer viaje alrededor del mundo. Noticias del mundo nuevo con las figuras de los paises que se descubrieron señalados, España, Red ediciones, 2011, pág. 10. ${ }^{25}$ Bartolomé de las CASAs, El libro de la primera navegación. Biblioteca Nacional de España, Sección de Manuscritos, Vitrina 6, número 7-17. Véase también Consuelo Varela (comp.), "Diario del Primer Viaje 1492" (Copia de Bartolomé de las Casas), Textos y documentos completos, Madrid, Alianza Universidad, 1982, págs. 23-24.

${ }^{26}$ Andrés González Barcia (comp.), "La Historia de Fernando Colón en la qual se da particular, y verdadera de la vida y hechos de D. Christoval Colón su padre, y del descubrimiento de las Indias Occidentales, llamadas Nuevo Mundo, que pertenece al Serenísimo Rei de España”, en Historiadores primitivos de las Indias Occidentales, Tomo I, Madrid, 1859, págs. 15-17.
} 
Según explica Fernando, finalmente mediante engaños, un discurso enérgico y la amenaza del castigo, Colón logró calmar algunos de los miedos y maquinaciones de su tripulación ${ }^{27}$. Como fuese que lo haya logrado, pese al capricho de los vientos atlánticos y del ánimo de los hombres, poco después la expedición logró alcanzar tierra en una latitud no reconocida hasta entonces por el europeo. Se comprende que al escribir su diario y luego al relatar personalmente lo sucedido a su hijo, Colón lo hiciera destacando las adversidades por las que atravesó para lograr su fin. Si bien ambos relatos pudieran haber sido dramatizados o en parte falseados, como por ejemplo en cuanto a lo que los hombres realmente hablaban del capitán, no se puede negar la veracidad de estos temores, pues fueron respuestas lógicas al entorno experimentado. En este sentido, no solo los marinos sintieron miedo, sino incluso el propio Colón, aún seguro como estaba de que tarde o temprano daría con tierra. Más tarde se hablarán de otros miedos descritos en su diario, por ahora sólo se puede mencionar que a estas alturas temía (aunque no lo dijera explícitamente en su diario) que la rebelión de su tripulación pudiera frustrar un viaje que organizó con tanta dificultad y que se consideraba casi imposible, victoria que sin duda le abriría las puertas a la fama y la fortuna.

Tras el encuentro con una nueva tierra y conforme aumentaron los descubrimientos y reconocimientos de nuevos destinos, a la par de la continuidad y constancia de los viajes ultramarinos, la casta marinera se fue acostumbrando a los largos recorridos sin tierra de por medio, a las calmas sin vientos que alargaban su duración y a la soledad marina. Después, fueron los pasajeros quienes sufrieron de este mal elemental, como nuevos peregrinos en aquellas travesías. Casi un siglo después del primer viaje colombino, es posible encontrar relatos como el de Eugenio de Salazar, quien en 1573 navegó desde Canarias hasta Santo Domingo para ocupar la plaza de oidor de la Audiencia de aquella isla. En una carta escrita a un amigo, deja escuchar la voz surgida de la insoportable espera que el paisaje marino provocó en un ser predominantemente terrestre:

...viéndose el hombre en un navío solo, sin ver tierra, sino cielo no sereno y agua, camina por aquellos reinos cerúleos, verdinegros, de suelo oscuro y espantoso, sin ver si se menea en un lugar ni conocer la estela de un navío, viéndose al parecer siempre rodeado de un mismo horizonte, viendo a la noche lo mismo que vio a la mañana, y hoy lo mismo que ayer, sin ver otra cosa alguna diversa.

\footnotetext{
${ }^{27}$ A. González Barcia, “La Historia de Fernando Colón...”, págs. 15-17.
} 
¿Qué gusto, qué alivio puede tener en el viaje, ni qué hora le puede dejar el enfado de tal camino y posada? ${ }^{28}$

Tanto en los diarios de viaje como en cartas personales de pasajeros, se puede encontrar este temor a los viajes largos, un miedo que aunque psicológico, producto de la percepción basada en las experiencias personales de cada hombre o mujer, se alimentaba del lento caminar de las horas y la dilatación del paisaje marino. A veces, éste parecía tan infinito que daba la impresión de que se habían recorrido dos mil leguas o más y que el camino no se podía andar más de una vez en la vida, y otra en la muerte ${ }^{29}$. Conforme aumentaron los viajes trasatlánticos, los viajeros frecuentes temían menos a la larga espera, sabedores de que en algún momento tocarían suelo firme. Sin embargo, algunos como Salazar, aunque sabían que viajaban hacia un lugar cierto, experimentaban por primera vez aquella terrible espera. En algunos otros, pese a la experiencia de varios viajes, persistió cierta ansiedad, quizás explicable por la soledad y falta de referencias a las que se ha hecho referencia. Ya decía el fraile José de Acosta: en el mar no se halla rastro de los que han caminado por él, ni se encuentran caminantes a quien preguntar en el camino $[\ldots]^{30}$.

\section{Una "mala navegación"}

Una embarcación en malas condiciones o su mal gobierno debido a la falta de habilidades del piloto o la tripulación, era transporte seguro hacia el naufragio. En ocasiones el problema venía desde su construcción, ya que las cuadernas no habían sido correctamente reforzadas o no eran de una madera resistente. También podía ser que los pernos que unían los tablones del casco u otras partes fueran de una mala aleación y la continua exposición al medio los deteriorara rápidamente. Además, los buques pasaban largas jornadas de navegación enfrentando las fuerzas del oleaje, las corrientes, los vientos, las tormentas y el hambre

\footnotetext{
${ }^{28}$ Eugenio de Salazar, "Carta escrita al licenciado Miranda de Ron, particular amigo del autor, en que pinta un navío, y la vida y ejercicios de los oficiales y marineros del, y como lo pasan los que hacen viajes por el mar. En útil para la noticia del lenguaje marino", "Apéndice 3. Eugenio de Salazar. La mar descrita por los mareados", en J. L. Martínez, Pasajeros de Indias..., págs. 289 y 291.

29 “Alonso Rodríguez a su hermano Juan Rodríguez, en La Puebla de Montalván”, Popayán, 4.II.1578, en Enrique Otte, Cartas privadas de emigrantes a Indias, 1540-1616, México, Fondo de Cultura Económica, 1996, pág. 355.

${ }^{30}$ Joseph de Acosta, "Libro primero. Capítulo XVII. De la propiedad y virtud admirable de la piedra imán para navegar; y que los Antiguos no lo conocieron", en Historia Natural y Moral de las Indias..., pág. 53.
} 
del molusco teredo navalis, mejor conocido como "broma" 31 , que perforaba la madera provocando la filtración del agua. La voracidad de este último fue uno de los motivos que provocó que durante el tornaviaje de la primera expedición alrededor del mundo, al mando del piloto Juan Sebastián Elcano (tras la muerte de Magalhães), algunos de los valerosos hombres prefirieran quedarse en la factoría portuguesa de Mozambique, con el riesgo de ser apresados, en vez de continuar una navegación con hambre y frío, en un buque que hacía mucha agua debido a los gusanos que roían el barco y las olas que dislocaban el casco. En el origen de su rebeldía se hallaba el miedo ${ }^{32}$. El propio cronista del rey, Gonzalo Fernández de Oviedo, quien también fue navegante, supo lo que era viajar en estas circunstancias un día en que salió del puerto de Santa Marta de la Antigua del Darién, Golfo de Urubá, rumbo La Española en 1523. La carabela de su propiedad estaba tan comida de la broma, que se hallaba inundada en medio de un mar agitado, mientras él y su tripulación trataban de tapar los agujeros del casco con sus camisas: pero dejemos las velas, que no son más de culpar que la madera de los árboles en este caso pues de ellas se hacen los navíos e másteles y entenas de ellos [...], decía el cronista de Indias: e ya yo me vi en la mar en tal término, que pudiera con más experiencia propria temer y entender los peligros de ella ${ }^{33}$. Esta experiencia debió dejar honda huella en Fernández, pues como se señaló en un principio, dedicó en su Historia General, un libro a los infortunios y naufragios, que muchos hombres como él padecieron en su accidentado andar trasatlántico.

Otra grave pérdida era la del timón, indispensable para gobernar y dar rumbo a la nave. En condiciones muy fuertes de oleaje y corrientes, se podían zafar los herrajes que unían sus partes y romperlo. A ello se refería Lope de Vega cuando decía cual nave rompe la trabada amura, y cual abalanzándose quebranta del voluble timón tres ferros corvos, por no tener para perderse estorbos ${ }^{34}$. Podía ocurrir en cualquier momento, como cuando a tan sólo tres días de su partida desde el puerto de Palos en 1492, Colón tuvo que hacer una parada de emergencia en las Canarias debido a que se rompió el timón de la Pinta, el cual Pinzón trató de arreglar atándolo con cuerdas. Colón sospechaba que se trataba de un sabotaje del propio propietario de la nave, Cristóbal Quintero, quien viajaba en aquella expedición a disgusto. Como fuere, el hecho es que debido a éste y otros

\footnotetext{
${ }^{31}$ Es un molusco bivalvo de la familia Teredinidae cuya especie más frecuente es el Teredo navalis.

32 J. FAVIeR, Los grandes descubrimientos. ..., pág. 261.

${ }^{33}$ Gonzalo Fernández de Oviedo, "Proemio (1)", en Historia General y Natural de las Indias V, Tomo CXXI, (estudio preliminar de Juan Perez de Tudela Bueso), libro L, Madrid, 1992, pág. 306.

${ }^{34}$ Lope de Vega, "Canto II. Desaparecida la Codicia, pide Francisco Draque a la reina navíos y gente para robar a Panamá. Elígele por general de la mar; y a Juan Achines, de la tierra. Cuéntase la jornada que su hijo Ricardo intentó a la mar del Sur por el estrecho de Magalhães”, en La Dragontea, España, Museo Naval, Ministerio de Marina Español, 1935, pág. 361.
} 
imperfectos, durante todo el viaje la tripulación se quejó, además de lo largo del viaje y del antojo de los vientos, de navegar en buques que tenían tantos defectos, que no podrían al salvar hombres que estaban tan dentro del Mar ${ }^{35}$. Una avería semejante sufrió el galeón Grande São João, en el que viajaba el célebre hidalgo Manoel de Souza Sepúlveda y su familia, desde Portugal hacia África en 1552. En la Historia Trágico-Marítima, según la narración de un anónimo, quien dijo basarse en el testimonio de uno de los sobrevivientes, el guardián Álvaro Fernández, tras tres días de una difícil navegación en un mar encrespado, el buque perdió primero el mástil y las velas. Después, cuando el carpintero informó al maestre del peligro en que se hallaban a causa de la avería del timón, en lo que está toda la perdición o salvación de una nao, consideró que lo mejor era ocultarlo para no causar terror y miedo a la gente, por lo que incluso no se le informó al capitán ${ }^{36}$. Aquí vemos nuevamente la intención de ocultar las condiciones de navegación reales para evitar que la gente entre en un estado de miedo "psicológico" ante un posible peligro "por venir", pues seguramente se pensaba que lo mejor era esperar a que la situación fuera irremediable para dar aviso.

En otras ocasiones los accidentes marítimos se debían a la ineptitud de los propios pilotos, no en balde algunos autores de tratados de náutica del siglo XVI se referían a ellos como "toscos", "rudos" o "faltos de entendimiento" 37 , y ello no estaba fuera de la realidad, pues pese a que se preparaban en la escuela de pilotos de la Casa de Contratación de Indias, su enseñanza era breve y más en la teórica que en la práctica. El motivo por el que Colón perdió la Santa María durante su primer viaje, fue que el piloto le dejó su gobierno a un grumete que la estrelló en unos bajos cerca de La Española. Mala decisión, tomada tras el cansancio de un largo y peligroso viaje. Asimismo, la catástrofe de la nao portuguesa Conceição en 1559 se atribuyó a un error del piloto. El pasajero Manoel Rangel fue testigo de que aquel no se fiaba de su punto ni del de su sol, y traía dos puntos, el de su sol y otro en la fantasía. Momentos antes de que el buque se estrellara en unos bajos, el guardián alertó al piloto de su equivocación, pero

\footnotetext{
${ }^{35}$ A. González Barcia, "La Historia de Fernando Colón ...”, págs. 15-17.

36 Bernardo Gomes DE Brito, "Relación de la notable pérdida del Galeón Grande San Juan en Natal”, en Historia Trágico-Marítima, México, Espasa-Calpe, 1948, pág. 20. Éste fue un naufragio muy famoso en su época, y las primeras narraciones escritas de manera anónima comenzaron a circular como folletos u hojas sueltas impresas por Lisboa entre 1555 y 1556. La primera edición se tituló: Relaçao da mui notável perda do galeáo grande S. Joáo, em que se contam os grandes trabalhos e lastimosas coisas que aconteceram ao capitáo Manuel de Sousa Sepúlveda e o lamentável fim que ele e sua mulher e filhos e toda a mais gente houveram na Terra do Natal, onde se perderam a 24 de junho de 1522.

${ }^{37}$ Pablo Emilio Pérez-Mallaína, Los Hombres del Océano. Vida cotidiana de los tripulantes de las flotas de Indias, Siglo XVI, Sevilla, Servicio de Publicaciones de la Diputación de Sevilla, 1992, pág. 48.
} 
éste respondió: id a mandar a los grumetes al combés, que yo sé lo que hago con $e t^{38}{ }^{38}$. Atestiguar tal insensatez producía un gran temor, por eso cuando el resto de pasajeros y tripulación se percató de la situación el llanto y el griterío [...] daba tanto miedo, explicó Rangel, que pareció el fin. A todo ello se sumó la mala noticia de que se había roto el timón y debido al pánico colectivo no había allí marinero, ni quien fuese a amainar, ni entendimiento para ello, y así andaban todos fuera de juicio $[\ldots]^{39}$.

Los desastres navales ocasionados por la pésima condición de las naves, así como por una "mala navegación" eran tan conocidos que se procuraba evitar viajar en naves "podridas" o conducidas por un mal reputado piloto. En 1572, Juana Bautista escribió desde México a su hermana Mariana de Santillán, residente en Sevilla para advertirle que no viajara en navíos podridos, porque no les acontezca alguna desventura ${ }^{40}$. Mientras que Fray Antonio de Guevara aconsejaba elegir galera afamada y fortunada, en la cual no haya acontecido alguna notable desdicha, pues era una imprudencia osarse nadie arrojar y aventurar su vida a do sabe que allí perdió otro su vida y la honra ${ }^{41}$. En ambos casos existía un estado de alerta común, provocado por el miedo reflexivo hacia un peligro conocido; aunque el primero se debió al sentido común (no viajar en buques viejos o dañados), mientras que el segundo parece aludir más a la superstición.

\section{Piratas y otros demonios}

La piratería es un modus vivendi tan antiguo como la navegación misma. Con la apertura de nuevas rutas atlánticas hacia el oriente y occidente, los ladrones de mar, autónomos o financiados por las naciones, persiguieron la estela de los navíos portugueses y españoles hasta sus colonias en África y las Indias. Durante su tercer viaje (1498-1500), el enemigo aguardaba los navíos de Colón a la altura del Cabo San Vicente, por lo que el almirante tuvo que cambiar de rumbo. Continuamente perseveraron los franceses, hasta que en 1522, cerca de las Azores, una flota encabezada por Jean Fleury (en realidad el oficial Giovanni de Verrazano), asaltó la escuadra del capitán Alonso de Ávila, la cual transportaba un excepcional tesoro: piedras preciosas, perlas, plumas exóticas y huesos

\footnotetext{
${ }^{38}$ B. Gomes DE BRito, "Relación del naufragio de la Nao Concepción en Pedro de los Baños. Francisco Nobre”, en Historia Trágico-Marítima..., pág. 139.

${ }^{39}$ Ibíd.

40 "Juana Bautista a su hermana Mariana de Santillán, en Sevilla", México, I8.III.1572, en Enrique Otte, Cartas privadas de emigrantes a Indias, 1540-1616, México, Fondo de Cultura Económica, 1996, pág. 66.

${ }^{41}$ Antonio de Guevara, "Capítulo X. De las cosas que el mareante se ha de proveer para entrar en la galera". Apéndice 1, De muchos trabajos que se dan en las galeras, 1539", en J. L. Martínez, Pasajeros de Indias..., pág. 232.
} 
de probablemente un mamut, que Hernán Cortés enviaba desde Tenochtitlán a Carlos V como presente ${ }^{42}$. La hazaña alentó al monarca François I a continuar su guerra de corso en las Antillas y el Caribe. Por eso, cuando Alvar Núñez Cabeza de Vaca pretendió regresar a España en 1537 tras su larga e infortunada aventura en esas tierras, tuvo que enfrentar el temor de encontrarse con franceses al salir de La Habana, pues había noticias de que éstos recién habían capturado tres buques españoles. Después, a casi un mes de zarpar, su nave fue perseguida por una vela enemiga durante la noche, para después, a su vez, ser confundidos con franceses por una flota portuguesa, historia en la que finalmente resultó escapado de todo peligro ${ }^{43}$.

El temor al asalto de piratas era latente en cada navegación, pues tenían fama de violentos y torturadores. Felipe II denunció que las agresiones efectuadas contra sus marinos eran con tanta crueldad y desvergüenza que aun los Turcos usan de mas piedad y clemencia con los Christianos ${ }^{44}$. En aquel entonces la guerra que mantenían España y Portugal con Francia acentuaba la confrontación en materia religiosa entre papistas y hugonotes, y a estos últimos se les acusaba de asesinar sistemáticamente a grupos de religiosos de la fe católica. En 1570, el pirata Jacques de Sores conocido por su "locura asesina" capturó una flota portuguesa que se dirigía a Brasil. Los treinta y nueve jesuitas a bordo fueron masacrados como castigo por su "equivocada elección" en materia de religión, mientras que sus imágenes, rosarios, libros y otras reliquias fueron arrojados al mar. Según el jesuita Louis Richeome, aquél "hereje" llamó a los religiosos enemigos de la verdad y les gritó con furia a la muerte, a la muerte, a los abismos todos los perros prontos, los frailes y jesuitas, que llevan la peste al Brasil ${ }^{45}$. Como se puede observar, en este episodio se enfatiza el uso de una violencia "teatralizada" contra una fe considerada "verdadera", que sin embargo, desde el punto de vista del agresor es una plaga social. Para muchos cristianos, los piratas eran una especie de enviados del infierno, así se entiende que en la poética religiosa de la época, una navegación perseguida por bandidos representara una metáfora de la lucha del viaje terrenal del bienaventurado que sortea el peligro para evitar que le roben su mayor tesoro: la gloria eterna.

Pero no sólo en la metáfora litúrgica se hallaba la lección divina. En tiempos de auge de la Carrera de Indias, ante la dura realidad del navegante, en la mentalidad de la sociedad ibérica atravesar el Mar Océano se consolidó como una oportunidad para que los espíritus devotos fueran puestos a prueba ante el poder

\footnotetext{
42 J. L. Martínez, Pasajeros de Indias..., pág. 121.

${ }^{43}$ A. González Barcia, "Naufragios de Álvar Núñez Cabeza de Vaca y Relación de la Jornada, que hizo a la Florida con el Adelantado Pánfilo de Narváez", en Historiadores primitivos..., pág. 42.

${ }^{44}$ Felipe II citado por M. Augeron, "Violences thétralisées...", pág. 285.

${ }^{45}$ Ibíd., págs. 288, 302.
} 
de Dios, por lo que además de los piratas, otros peligros asechaban al navegante. Fernández de Oviedo menciona haber conocido a marinos y a otras personas de crédito que habían escuchado voces como humanas hablar en el aire, en los tiempos que más peligro tenían, e han visto cosas espantables e demonios ${ }^{46}$. Con estos testimonios, el cronista redactó varios de sus relatos. Uno de ellos es sobre unas mujeres conocidas como las "Taviras", basado en lo que éstas le contaron a él y a otro interlocutor racional, el licenciado Alonso de Zuazo, uno de los oidores de la Real Audiencia de Valladolid. Durante el viaje de una carabela desde Santa Marta de la Antigua del Darién, Golfo de Urubá, hacia Cuba en el año de 1519 , en medio de una borrasca y ante el peligro de estrellarse en una costa rocosa, aquellas pasajeras vieron diablos muy fieros y espantables puestos a la proa e popa de la nao que decían tuerce la vía y échala a fondo; anégala, refiriéndose al destino del navío. Según esto, escucharon a uno de ellos replicar que no podía hacerlo porque a bordo iba la Guadalupe (en realidad, un fraile con las limosnas para dicha virgen). En aquel momento la gente comenzó a llorar y gritar aterrorizada, elevando sus plegarias ${ }^{47}$ y poco después, "sorbidos" entre las ondas del mar, los pasajeros vieron unos pescados como grandes toñinas o delfines que asían con sus dientes los tablones del casco del navío y los arrancaban, provocando que entrase más agua, de manera que no se podían valer; ni fuera posible salvarse sino milagrosamente ${ }^{48}$. Es probable que el testimonio o la narración de estos hechos hayan sido exagerados o en parte inventados con el fin de probar la devoción religiosa de las testigos hacia la virgen; sin embargo, al formar parte de una historia oficial, junto con otros relatos semejantes, muestra la necesidad de enaltecer los valores de la España católica (a través de las vicisitudes de sus súbditos) al enfrentar los peligros de este y el otro mundo ${ }^{49}$.

Tal parece que el cronista de Indias sentía una fascinación especial por el tema de las visiones demoníacas, y en otra de sus relaciones, el propio Zuazo fue testigo presencial de extrañas apariciones durante uno de los más terribles y "milagrosos" naufragios en la historia de la navegación hispánica. Al emprender un viaje de Cuba a México en 1524, con el objeto de arreglar cierta rencilla entre Hernán Cortés y el gobernador de la isla de Jamaica, y tras entrar en el Golfo de México, su carabela fue atrapada por una poderosa tormenta. Entonces, veían en la oscuridad, una luz que los guiaba,

\footnotetext{
${ }^{46}$ G. Fernández de Oviedo, "Capítulo VIII. De tres naos que escaparon milagrosamente con toda la gente de ellas, estando doscientas leguas o más en la mar, e aportaron al puerto de Plata en esta isla Española", en Historia general..., pág. 320

${ }^{47}$ G. Fernández de Oviedo, "Capítulo IX. De la carabela que llamaron de las Taviras por el caso maravilloso, que aquí será contado, que obró Dios e su gloriosa Madre por estas mujeres e otras personas que en este naufragio se hallaron”, en Historia general..., pág. 321.

${ }^{48}$ Ibíd., pág. 322.

${ }^{49}$ V. Moya Sordo, "Miedo en el navío inestable...", pág. 127.
} 
En el cual tiempo e trabajo vieron muchas toninas grandes o pescados de aquella manera como puercos cebones, que parescían que volaban por el aire alrededor del navío, con otras señales horribles y espantosas, sin esperanza de la vida, e sin saber adónde estaban ni poder gobernar el navío $[\ldots]^{50}$.

Sin duda, los efectos físicos de las tormentas marinas podían provocar ciertas "visiones" en las conciencias temerosas, interpretadas como señales de un peligro cercano. En aquel entonces se pensaba que los demonios operaban detrás de los desastres naturales y los sentidos humanos. Un siglo más tarde, todavía se buscaba explicación a ello, como se lee en los Milagros, o más propiamente de los admirables Diabólicos (1631), del militar y político Antonio Ardoino, marqués de Lorito, donde afirma que los demonios buscaban traicionar los sentidos humanos trastornando los raios de la luz reflexiva de los objetos, para falsificar las apariencias de las figuras ${ }^{51}$. Al ser los maestros del disfraz y los manipuladores de las fuerzas naturales, el mar salvaje fue lugar propicio para que los demonios confundieran a las almas, poniendo a prueba su fe durante los eventos más difíciles. Se entiende entonces que Fernández de Oviedo (quién se decía un hombre de verdades), asegurara que aquellos seres que se vieron volar sobre los mástiles y antenas de la carabela eran diablos, e no pescados que pusieron a prueba la fe de Zuazo, hasta que Dios lo libró de sus enemigos espirituales ${ }^{52}$. Así vemos que esta creencia popular no era sólo propia de individuos iletrados y supersticiosos, sino también de ilustrados y respetables como Zuazo y Oviedo.

Estas apariciones también frecuentaron las vías de los portugueses. Previamente al naufragio de la nave São Bento del capitán Fernão Álvarez Cabral, la cual iba sobrecargada sorteando un temporal cerca del Cabo de Buena Esperanza en 1554, según testimonio del experimentado navegante y cartógrafo Manuel de Mesquita Perestrelo, en un momento de gran temor colectivo debido a la marejada y a la poca confianza que se tenía en el accidentado buque, un marinero comenzó a santiguarse e invocar a Jesús. Cuando algunas personas le preguntaron la causa, éste señaló por la banda de estribor una enorme ola, diciendo que delante de ella veía venir una grande folía de bultos negros que no podían ser

\footnotetext{
${ }^{50}$ G. Fernández de Oviedo, "Capítulo X. Relación del naufragio del Licenciado Zuazo”, en Historia general..., pág. 293

${ }^{51}$ Antonio Ardoino, Exámen Apologético de la Histórica Narración de los Naufragios, Peregrinaciones, i Milagros de Alvar Nuñez Cabeza de Baca en las Tierras de la Florida i del Nuevo México, en A. González Barcia, Historiadores primitivos ..., págs. 25-29.

52 Ibíd., págs. 356-357.
} 
más que diablos, lo que causó que la gente se espantara y aumentara sus gritos ${ }^{53}$. Como se puede notar en este y los casos anteriores, el miedo a las apariciones demoniacas coincidía con situaciones de grave peligro en un espacio en el que no se tiene control, donde las fuerzas de la naturaleza formaban parte esencial en los misterios y milagros de los navegantes.

\title{
Mar de tempestades y naufragios
}

La tempestad solía ser una terrible experiencia para los nautas que navegaban mar adentro, entre la oscuridad del cielo, las tinieblas, la violencia de los vientos, los truenos y relámpagos, así como grandes cantidades de agua precipitándose sobre el frágil navío. Leonardo da Vinci describió en su tratado "Del mundo y sus aguas" (Di mondo ed acque, 1508), cómo había de representarse la anatomía de una tormenta oceánica:

\begin{abstract}
El mar estará enfurecido, tempestuoso y espumeante al mismo tiempo que cubierto de densa niebla. Los barcos, con las velas desgarradas, con andrajos azotados por el viento, las maromas rotas y los mástiles cargados y caídos, apareciendo el mismo buque destrozado por las olas y con los pasajeros chillando y agarrándose furiosamente a los restos del naufragio [...] Todo el ambiente debe inspirar terror producido por la oscuridad que causan las nieblas y las espesas nubes. ${ }^{54}$
\end{abstract}

El florentino simbolizó el fenómeno con un realismo onírico: una explosiva fuerza vital; destructiva, brutal y alucinante, frente a la cual el hombre, debilitado y temeroso, se dibuja como el objeto de su capricho. Cualquier navegante experimentado del mundo ha vivido alguna vez una experiencia semejante, y por más curtido y valiente que sea, ha tenido que acostumbrar su corazón al sobresalto de tal furia. En el tornaviaje de 1493, La Niña y La Pinta fueron atrapadas por una tormenta después de dejar atrás las Azores, lo que las mantuvo extraviadas durante una semana. Fue tal el peligro, que al almirante lo asaltó el temor de morir sin haber conseguido llegar a España y dar noticia de su descubrimiento. Según los fragmentos que Bartolomé de la Casas recuperó de su diario, Colón mantenía la esperanza de que Dios le diera valor y ayudara a terminar su viaje,

\footnotetext{
${ }_{53}$ B. Gomes DE BRito, "Relación del naufragio de la Nao Sao Bento en el Cabo de Buena Esperanza, durante el viaje que hizo el capitán Fernando Álvarez Cabral”, en Historia Trágico-Marítima..., pág. 51.

${ }^{54}$ Leonardo da VINCI, "Cómo se representa una tempestad", en Tratado de Pintura, Madrid, Editora Nacional, 1983, págs. 414-415.
} 
ya que lo había librado de los peligros de la ida, cuando los marineros se alzaron contra él determinados a volver ${ }^{55}$. Sin embargo, su flaqueza y congoja no lo dejaban asensar la anima ${ }^{56}$. De esta forma, Colón expresa abiertamente su miedo a los elementos, no así a los hombres, demostrando con ello que su coraje se rendía sólo ante el poder supremo. Pero esta no fue ni la primera ni la última tempestad que temió el almirante. Cuando realizó su cuarto viaje a las Indias desde Portobelo rumbo a Veragua (Panamá), lo sorprendió tal temporal que sus hombres y él le temían al fuego por los raios, i los relampagos, el aire, por su furia; el agua, por las olas, i la tierra, por los bagios, i escollos de costa no conocid ${ }^{57}$. Un miedo semejante se vivió al regreso del navío del capitán Jorge Albuquerque Coelho de Brasil en 1565, cuando durante una espantosa tormenta, el mar y el viento crecían cada vez más, y andaban todos tan temerosos con los resplandores y relámpagos que había, que parecía fundirse el mundo ${ }^{58}$. El camino del mar tempestuoso era temido por capitanes, pilotos, oficiales, marineros, pero sobre todo, por los pasajeros. Por lo mismo, muchos de ellos solamente hicieron un solo viaje en toda su vida. Desde México, María Díaz escribió con clara franqueza a su hija en Sevilla en 1557 sobre los grandes trabajos y peligros que vivieron ella y su marido durante su viaje a la Nueva España. Le explicó que de haber sabido, no lo habría hecho debido a las tormentas, sobre todo una que duró dos días, donde pensaron perecer en la mar, porque fue tan grande la tempestad que quebró el mastel de la nao $[\ldots]^{59}$.

La tempestad representó para el que la vivió, entre visiones y apariciones del más allá, el caos en medio de una batalla material y espiritual donde se disputaban la estabilidad del navío y la vida y alma de sus tripulantes. Los relatos de Fernández de Oviedo y de Brito están plagados de estos terroríficos escenarios, destinados casi siempre al naufragio. Este último representaba la pérdida del único sustento sólido entre la superficie y las profundidades marinas; significaba la posibilidad de la muerte, no sin antes flotar a la deriva por un periodo incierto de tiempo o luchar desesperadamente para evitar ahogarse. Como ya se vio, aunque un naufragio podía ocurrir debido a las malas condiciones de la embarcación o de su gobierno, a un ataque enemigo, o bien entre otras causas como un incendio; sin embargo, casi siempre fue una tormenta la que hundió un buque y causó la muerte de cientos de hombres. Fernández de Oviedo, al igual que mu-

\footnotetext{
${ }^{55}$ C. Colón, "Diario del Primer Viaje...", pág. 127.

${ }^{56}$ Íd. ibíd.

57 A. GonZález Barcia, Historiadores primitivos..., pág. 108.

${ }^{58}$ B. Gómez DE Brito, "Naufragio que pasó Jorge de Albuquerque Coelho", en Historia TrágicoMarítima..., pág. 31.

59 “María Díaz a su hija Inés Díaz, en Sevilla. México, 31.III, 1577”, en E. Otte, Cartas privadas..., pág. 97.
} 
chos sobrevivientes de aquellos "infortunios", los atribuyeron a los designios de Dios. En cambio, de Brito, con un siglo más de tiempo para evaluar la historia marítima portuguesa, responsabilizó a la negligencia, la falta de responsabilidad y la codicia humana, el que los buques navegaran averiados o durante climas adversos.

En el naufragio se jugaba la existencia azarosa de los náufragos, seres al borde de la desesperación y la esperanza, quienes compartían un temor y una experiencia colectivos. Momentos antes de la pérdida de la nao Conceição, cuando parecía el fin, todos juntos con los crucifijos y retablos pidieron perdón a Dios por sus culpas y pecados, se confesaron con los sacerdotes a bordo con tal prisa que no dejaban lugar los unos a los otros y se abrazaron con gran fraternidad y lloros $^{60}$. Como se ha visto, la principal manifestación del miedo ante el peligro de naufragar eran los gritos, lamentos y llantos de desesperación. Miguel de Cervantes conocía bien este ritual, pues había navegado y sufrido tormentas. En su novela El amante liberal, por ejemplo, el personaje Ricardo realiza un viaje en busca de su amada Leonisa, y cuando su galeota está a punto de anegarse al comenzar la noche, gritan y se sobresaltan los que se sienten perdidos,

que ninguna cosa de las que nuestro arráez mandaba se entendía ni se hacía; sólo se atendía a no dejar los remos de las manos, [...] y echar las dos áncoras a la mar, para entretener con esto algún tiempo la muerte, que por cierta temían ${ }^{61}$.

Ocupados en la lucha por la supervivencia, entretenidos en arriar velas y cabos, y en achicar el agua, los hombres aplacaban los posibles desenfrenos del miedo contenido y el contagio del pánico. Sin embargo, en ocasiones el esfuerzo era en vano, como ocurrió con la embarcación São Bento. A punto de hundirse, el capitán ordenó que cesaran los esfuerzos y un pasajero confesó que entonces perdieron la esperanza, ya que el agua entraba por un costado como podía entrar por una canasta y por debajo todo estaba abierto e inundado, por lo que cada uno trató de encomendarse a Dios ${ }^{62}$. Lope de Vega describe, a su estilo, este camino a la desesperanza:

No hay cosa ya que el miedo no lo ocupe, crece la tempestad, el viento crece, tres rayos juntos una nube escupe a un leño que parece que perece. [...] Cual se confiesa aprisa, cuál se abraza con el

\footnotetext{
${ }^{60}$ B. Gomes DE Brito, "Relación del naufragio de la Nao Concepción...”, pág. 139.

${ }^{61}$ Miguel de Cervantes, "El amante liberal", en Obras Selectas, EDIMAT, 2000, pág. 75.

${ }^{62}$ B. Gomes DE BRIto, "Relación del naufragio de la Nao Sao Bento...", pág. 53
} 
amigo, cuál la imagen besa, cual mira si ha de haber alguna traza para escaparse en caja o tabla gruesa. Ya no hay ;bota a estribor, larga ni caza! Ya del reloj la armonía cesa, ya la luz se les muere, ya se apaga, y abriendo el mar la boca se lo traga ${ }^{63}$.

Con la eventualidad del naufragio venían también otros miedos. Unos ante la posibilidad de sobrevivir y otros ante la de morir. La primera, aunque parezca contradictoria, no dejaba de ser aterradora, pues implicaba tener que enfrentar una nueva etapa de sufrimiento y lucha en una larga e inesperada agonía. Aquellos que lograban asirse a un bote o a unas tablas entraban en un nuevo proceso donde no había alimentos ni agua, ni timón o vela que los guiara por el líquido elemento, a merced de los ardientes rayos del sol y la fría oscuridad de la noche. Muchos, además, temían ir a dar a tierras extrañas y caer en manos de "salvajes". Éste fue el sentimiento del anónimo testigo del naufragio del Grande São João cerca del cabo de Buena Esperanza, al informarle de la posibilidad de desembarcar en una playa: ;Verdaderamente los hombres creyeron que esto causa gran espanto! Vienen con este galeón a varar en tierra de cafres, teniéndolo por el mejor remedio para sus vidas, siendo éste tan peligroso $[\ldots]^{64}$.

Cuando dos años después también la nao São Bento se encontró en peligro cerca de la costa africana a punto de zozobrar, todos sentían temor pues bien tenían en la memoria cuán cubiertos debían estar todavía sus extensos y desaprovechados bosques de osamentas portuguesas ${ }^{65}$. Ello se entiende mejor al conocer el desenlace de la historia del naufragio del São João en el Cabo de Buena Esperanza, entre cuyos sobrevivientes se hallaba el otrora mencionado Manoel de Souza, quien tuvo que peregrinar por desoladas tierras africanas, perdiendo hijo, esposa, y casi la razón con tantas desgracias. Su historia es narrada por de Brito, pero llegó a ser tan famosa que Luis de Camoes dedicó un canto (V) de Os Lusiadas (1572) a su "triste ventura", mientras que el poeta Jerónimo Corte Real unos versos (1594). También Lope de Vega y Tirso de Molina fueron inspirados por esta tragedia para escribir respectivamente Don Manuel de Sousa o el naufragio prodigioso y el príncipe trocado (1598 -1600), así como Escarmientos para el cuerdo $(1619)^{66}$. Como se dijo, sobrevivir al desastre implicaba el retorno de horrores ya padecidos o nuevos peligros al arribar a tierras desconocidas. La otra posibilidad era la extinción.

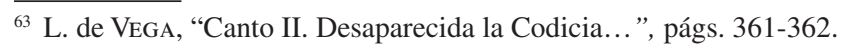

${ }^{64}$ B. Gomes de Brito, "Relación de la notable pérdida...", pág. 23.

${ }^{65}$ B. Gomes de Brito, "Relación del naufragio de la Nao Sao Bento...", pág.55.

${ }^{66}$ Alma Delia Miranda Aguilar, Modelos Ibéricos de Narraciones de Naufragios (siglos XVI y XVII), Tesis de maestría en letras españolas (inédita), México D. F., UNAM, 2006, págs. 99-104.
} 


\section{La muerte}

Don Pedro de Cantoval, viejo residente en la provincia de Nueva Galicia escribió en 1565 a sus hijos en España invitándolos a que lo visitaran, diciéndoles: no seáis pusilánimes, que pues os lo mando lo hagáis y no otra cosa, aunque penséis morir $^{67}$. La idea de cruzar el mar significaba para muchos la posibilidad de muerte en los múltiples peligros de la vastedad oceánica. Fray Tomás de la Torre, quién viajó en mares tempestuosos, bien decía: navegar es traer siempre la muerte a los ojos y no distar de ella más que el grueso de una tabla pegada a otra con $p e z^{68}$. Por su parte, sabedor por propia experiencia de esta trágica posibilidad y en un contexto donde el Ars moriendi era una buena costumbre, el predicador fray Antonio de Guevara recomendaba a todo pasajero que es de nación cristiano y de Dios temeroso, que estuviera preparado para que una vez llegada una mala borrasca se encomendara a algunos notables santuarios, se arrepintiera de sus pecados y se reconciliara con sus compañeros ${ }^{69}$.

En el preludio a la muerte, en la cubierta de la Santa María da Barca, inutilizada por una tormenta durante su viaje al África en 1559, no podían poner los ojos en parte alguna en la que no se vieran rostros cubiertos de tristes lágrimas y de una amarillez y tránsito por el manifiesto dolor y excesivo espanto que causaba la llegada de la muerte ${ }^{70}$. Para la mayoría, más valía una muerte pronta y "digna", que una lenta de gran sufrimiento, sucumbiendo al terror y la agonía, como la que sufrieron los náufragos del São Bento, que al estrellarse en unos agudos peñascos, atestiguaron la carnicería que la furia del mar hacía en cada uno: los que no podían nadar más comenzaban a ahogarse, otros, agotados, se dejaban ir al fondo encomendándose a Dios; a otros los golpeaban las cajas y las olas, o chocaban contra los arrecifes o con afilados pedazos de la nave, y el agua andaba en diversas partes manchada de un color tan rojo como la propia sangre $^{71}$. No es difícil imaginar muerte más ruin. Sin embargo, había quienes preferían este fin, como el piloto de la Santa María da Barca, quien dirigió el buque hacia unos bajos pues era mejor morir a lanzadas, que morir ahogado ${ }^{72}$. El miedo a una muerte tortuosa era generalizado. Ello se hizo realidad en la

\footnotetext{
67 "Pedro de Cantoval a sus hijos Pedro y Diego de Cantoval, en Aguilar de Campo", México, 15.11.1565, en E. Otte, Cartas privadas..., pág. 48.

${ }^{68}$ Tomás de la Torre, "II. De lo que les pasó a los religiosos desde que se embarcaron hasta que llegaron a la isla de la Gomera", en J. L. Martínez, Pasajeros de Indias..., pág. 249.

${ }^{69}$ Antonio de Guevara, "Capítulo IX. De una sotil discreción de la mar y de sus peligrosas propiedades", Apéndice 1...", pág. 220.

${ }^{70}$ Fragmento del Relato II de Gomes de Brito citado en Isabel Soler, El nudo y la esfera. El navegante como artífice del mundo moderno, Barcelona, El Acantilado, 2003, pág. 228.

${ }_{71}$ B. Gomes de Brito, "Relación del naufragio de la Nao Sao Bento...", pág. 57.

${ }^{72}$ B. Gomes De Brito, "Relación del naufragio de la Nao Santa María...”, pág. 177.
} 
fatal expedición del licenciado Zuazo, cuando engullidos por enormes olas, entre enloquecedoras visiones, se estrellaron en unos bajos bravos y ásperos. Los sobrevivientes lucharon por aferrarse a las rocas:

...con las ondas de la mar algunas veces tan altas, que pasaban por encima de esta miserable compañía, con tan grand furia, que apenas abrazados con las peñas se podian sostener, e a algunos arrancaban e los desmembraba e hacía pedazos entre las rocas. ${ }^{73}$

Finalmente, morir en el mar podía significar hacerlo en pecado. Cuando la nao São Bento estuvo a punto de zozobrar, el navegante Manuel de Mesquita Perestrelo decía no ver a nadie a bordo en cuyo rostro no se reflejase el susto que recibía con aquel desengaño, por el recelo que ante tan justo Juez cada uno llevaba en sus injustas obras ${ }^{74}$. Por ello, muchos se negaban a realizar el viaje, lo que incluso llegó a ser un problema de Estado, pues peligraba la realización de los viajes y la migración de pobladores para los nuevos territorios. Por ello, a finales del siglo XVI se pretendió obligar a los marineros a portar cédulas de confesión, mientras que algunas ordenanzas españolas recomendaban que el capitán vigilara que su tripulación viviera "Christianamente y en el temor de Dios" "75. El miedo era no poder alcanzar la gloria divina, pero también no poder ser enterrado una vez muerto. Esto constituía una verdadera desgracia, pues se creía que un cuerpo a la deriva no podría encontrarse para la resurrección gene$\mathrm{ral}^{76}$, por lo que las almas estaban condenadas a vagar, expresando sus lamentos en el silbido del viento y el graznido de las gaviotas.

$$
* * *
$$

En todos estos escenarios, el miedo se presentó con diferentes rostros y reacciones, acompañando al hombre hasta su final, ya fuese de vida o de muerte, incluso hasta el más allá. Algunos de los temores fueron provocados por la sensación de peligro que despertaba la propia naturaleza del mar en su extensión y fenómenos climatológicos, donde el hombre se sentía vulnerable a causa de su incipiente y frágil tecnología, pero también por aspectos de su cultura relacio-

\footnotetext{
73 G. Fernández de Oviedo, “Capítulo IX. De la carabela...”, págs. 293-325.

74 B. Gomes de Brito, "Relación del naufragio de la Nao Sao Bento...”, pág. 53. El relato original titulado "Naufragio da não São Bento" fue escrito por Mesquita Perestrelo (Coimbra, 1564).

75 Ordenanzas del buen gobierno de la armada del mar océano (24 de enero de 1633), Madrid, Instituto Histórico de Marina, 1974.

${ }^{76}$ Michel Mollat Du Jourdin, Europa y el Mar. La construcción de Europa, Barcelona, Crítica, 1992, pág 208
} 
nados con creencias cristianas acerca del pecado, la muerte y el infierno. Así, los miedos no fueron únicamente manifestaciones espontáneas en respuesta a estimulaciones externas o internas, sino producto de la mentalidad de su tiempo en un intento por comprender la existencia del hombre ante el entorno marino.

Algunos de estos miedos se percibieron en sus fuentes de manera clara, cruda y sin pretensiones, como en las cartas de algunos pasajeros, pero otros fueron sublimizados en el discurso narrativo con el fin de reflejar, en contraposición a la adversidad, la valentía o alta moral de ciertos personajes o sociedades. Así, el carácter virtuoso de Colón, de Zuazo o las Taviras, se contraponía al del resto de los hombres, pues se advierte que pese a que sintieron miedo, no fue por cobardía, sino por temor a Dios, lo que les ayudó a exaltar su fe y enfrentar con ello la fatalidad. Pero más allá de esta retórica moralista, en la historia de la navegación trasatlántica, el riesgo y el miedo jugaron papeles íntimamente relacionados y trascendentales para el impulso de los viajes. Pese a los sentimientos, ideas o reacciones contrarias que pudieron desencadenar en los individuos o en la colectividad viajante, e independientemente del sometimiento o resignación que pudieron generar en algunos casos, en su mayoría fueron provocadores de impulsos de enfrentamiento creativo, de protección y supervivencia, que llevaron a las sociedades marítimas a desafiarlos en el deseo de superar las adversidades que representaba la gran barrera natural. De esta forma, además del desarrollo de la tecnología y el arte de navegar, los hombres realizaron actos de prevención, perseverancia y fe. De esta manera, antes de zarpar se proveían de testamentos, seguros de viaje, asistían a misa o se confesaban. Asimismo, durante un accidente, el miedo ponía en acción ciertas faenas para tratar de mantener el navío a flote, o para alzar cantos y rezos pidiendo ayuda celeste para enfrentar los peligros inmediatos o por venir. Al final, todo dependía del destino, por lo que si había que atravesar el Atlántico, el mejor consejo era: no miréis que hay agua en el camino, que cuando Dios quiere, tan presto se muere uno en la tierra como el agua ${ }^{77}$. Después de todo, quienes se adentraron en los dominios del mar para explorarlo, encontraron las formas más eficaces para confrontar y en algunos casos superar los temores que los acompañaron en sus viajes: la experiencia, la audacia y la esperanza.

\footnotetext{
${ }_{77}$ Carta de "Juan Muñoz a su sobrino Francisco Muñoz, en Berzocana", Puebla, 20.IV.1595, en E. Otte, Cartas privadas..., pág. 126.
} 


\section{BIBLIOGRAFÍA}

Acosta, Joseph de, Historia Natural y Moral de las Indias, Tomo Primero, Madrid, Pantaleón Aznar, 1792.

Augeron. Mickaël y Mathias Tranchant (comps.), La Violence et la Mer dans l'espace atlantique (XIIe-XIXè siècle), Collection Histoire, Presses Universitaires de Bennes, 2004.

Bourke, Joanna. "Fear and anxiety: writing about emotion in Modern History", History Workshop Journal, 55 (2003), págs. 111-133.

Casas, Bartolomé de. El libro de la primera navegación y descubrimiento de las Indias (Biblioteca Nacional de España, Sección de Manuscritos, Vitrina 6, número 7). Biblioteca Digital Hispánica [en línea], disponible en <http://bibliotecadigitalhispanica.bne.es/view/ action/nmets.do $>$ [Consulta: marzo 2013] .

Historia de las Indias (Biblioteca Nacional de España, Sede de Recoletos, Sala Cervantes, Fondo Antiguo, MSS/2812 V. 1, 2 y 3). Biblioteca Digital Hispánica [en línea], disponible en <http://bibliotecadigitalhispanica.bne.es/view/action/nmets.do $>$ [Consulta: marzo 2013] .

Corbin, Alain y Hélène Richard, El mar. Terror y fascinación, Barcelona, Paidós, 2005.

Cervantes, Miguel de, "El amante liberal”, Obras Selectas, Madrid, EDIMAT, 2000.

Colón, Cristóbal, Textos y documentos completos (comp., pról. y notas de Consuelo Varela), Madrid, Alianza Universidad, 1982.

Covarrubias, Sebastián de, Tesoro de la Lengua Castellana o Española [1611], Barcelona, Horta, 1943.

Delumeau, Jean, El miedo en Occidente (siglos XIV-XVII). Una ciudad asediada, Madrid, Taurus, 1989.

Domínguez, Vicente, "El miedo en Aristóteles", Psicothema, vol. 15, núm. 4 (2003), págs. 662-665 [en línea], disponible en <http://psicothema.com> [Consulta: 03/08/2009] .

Favier, Jean, Los grandes descubrimientos. De Alejandro a Magallanes, México, Fondo de Cultura Económica, 2004.

Fernández de Oviedo, Gonzalo. Historia General y Natural de las Indias V (estudio preliminar de Juan Perez de Tudela Bueso), Tomo CXXI, Libro L, Madrid, 1992.

Gil Fernández, Luis, Los Studia Humanitatis en España durante el reinado de los Reyes Católicos, Universidad Complutense de Madrid, [en línea], disponible en <http://ler.letras. up.pt/uploads/ficheiros/2957.pdf> [Consulta: 11/05/2008] .

Gomes de Brito, Bernardo, Historia Trágico-Marítima, México, Espasa-Calpe, 1948.

González Barcia, Andrés (comp.), Historiadores primitivos de las Indias Occidentales, tomo I, Madrid, 1859.

Jáidar Matamoros, Isabel (comp.), Los dominios del miedo, Área Subjetividad y Procesos sociales, México, UAM-XOCHIMILCO, 2002.

Martínez, José Luis, Pasajeros de Indias. Viajes trasatlánticos en el siglo XVI, México, Fondo de Cultura Económica, 1999.

Mollat Du Jourdin, Michel, Europa y el Mar. La construcción de Europa, Barcelona, Crítica, 1992. 
Moya Sordo, Vera, "Miedo en el navío inestable. Navegaciones atlánticas hispánicas, siglos XV-XVII", en Traversea: Journal of Trasatlantic History, vol. 2 (2012), págs. 116-130 [en línea], disponible en <http://www.uta.edu/history/traversea/ojs/index.php/traversea/ article/view/28>

Nicholl, Charles, Leonardo. El vuelo de la mente, Madrid, Taurus memorias y biografías, 2005.

Otte, Enrique, Cartas privadas de emigrantes a Indias, 1540-1616, México, Fondo de Cultura Económica, 1996.

Ordenanzas del buen gobierno de la armada del mar océano (24 de enero de 1633), Madrid, Instituto Histórico de Marina, 1974.

Pérez-Mallaína, Pablo Emilio, Los Hombres del Océano. Vida cotidiana de los tripulantes de las flotas de Indias, Siglo XVI, Sevilla, Servicio de Publicaciones de la Diputación de Sevilla, 1992.

Pigafetta, Antonio, Relación del primer viaje alrededor del mundo. Noticias del mundo nuevo con las figuras de los paises que se descubrieron señalados, España, Red ediciones, 2011.

Pralon-Julia, Dolores, "Una teoría del miedo en el siglo XVII: el De metu... de Cabreros de Avendaño”, Criticón, núm. 23 (1983), pág. 6 [en línea], disponible en <http://cvc.cervantes.es> [Consulta: 19/08/2009] .

Soler, Isabel, El nudo y la esfera. El navegante como artífice del mundo moderno, Barcelona, El Acantilado, 2003.

Vega, Lope de, La Dragontea, España, Museo Naval, Ministerio de Marina Español, 1935. 